\title{
Degree of Biomass Conversion in the Integrated Production of Bioethanol and Biogas
}

\author{
Krzysztof Pilarski $^{1, *}$, Agnieszka A. Pilarska ${ }^{2, *}{ }^{\mathbb{D}}$, Piotr Boniecki ${ }^{1}$, Gniewko Niedbała ${ }^{1}\left(\mathbb{D}\right.$, Kamil Witaszek $^{1}{ }^{1}$, \\ Magdalena Piekutowska $^{3}{ }^{\oplus}$, Małgorzata Idzior-Haufa ${ }^{4}$ and Agnieszka Wawrzyniak ${ }^{1}$ \\ 1 Department of Biosystems Engineering, Poznań University of Life Sciences, Wojska Polskiego 50, \\ 60-627 Poznań, Poland; bonie@up.poznan.pl (P.B.); gniewko.niedbala@up.poznan.pl (G.N.); \\ kamil.witaszek@up.poznan.pl (K.W.); agnieszka.wawrzyniak@up.poznan.pl (A.W.) \\ 2 Department of Dairy and Process Engineering, Poznań University of Life Sciences, ul. Wojska Polskiego 31, \\ 60-624 Poznań, Poland \\ 3 Department of Geoecology and Geoinformation, Institute of Biology and Earth Sciences, Pomeranian \\ University in Słupsk, ul. Partyzantów 27, 76-200 Słupsk, Poland; magdalena.piekutowska@apsl.edu.pl \\ 4 Department of Gerodontology and Oral Pathology, Poznan University of Medical Sciences, ul. Bukowska 70, \\ 60-812 Poznan, Poland; midziorhaufa@ump.edu.pl \\ * $\quad$ Correspondence: pilarski@up.poznan.pl (K.P.); pilarska@up.poznan.pl (A.A.P.); Tel.: +48-61-846-60-78 (K.P.); \\ $+48-61-848-73-08$ (A.A.P.)
}

Citation: Pilarski, K.; Pilarska, A.A.; Boniecki, P.; Niedbała, G.; Witaszek, K.; Piekutowska, M.; Idzior-Haufa, M.; Wawrzyniak, A. Degree of Biomass Conversion in the Integrated Production of Bioethanol and Biogas. Energies 2021, 14, 7763. https:// doi.org/10.3390/en14227763

Academic Editor: Byong-Hun Jeon

Received: 15 October 2021

Accepted: 16 November 2021

Published: 19 November 2021

Publisher's Note: MDPI stays neutral with regard to jurisdictional claims in published maps and institutional affiliations.

Copyright: (C) 2021 by the authors. Licensee MDPI, Basel, Switzerland. This article is an open access article distributed under the terms and conditions of the Creative Commons Attribution (CC BY) license (https:// creativecommons.org/licenses/by/ $4.0 /)$.

\begin{abstract}
The integrated production of bioethanol and biogas makes it possible to optimise the production of carriers from renewable raw materials. The installation analysed in this experimental paper was a hybrid system, in which waste from the production of bioethanol was used in a biogas plant with a capacity of $1 \mathrm{MW}_{\mathrm{e}}$. The main objective of this study was to determine the energy potential of biomass used for the production of bioethanol and biogas. Based on the results obtained, the conversion rate of the biomass-maize, in this case-into bioethanol was determined as the efficiency of the process of bioethanol production. A biomass conversion study was conducted for 12 months, during which both maize grains and stillage were sampled once per quarter (QU-I, QU-II, QU-III, QU-IV; QU-quarter) for testing. Between 342 L (QU-II) and 370 L (QU-I) of ethanol was obtained from the organic matter subjected to alcoholic fermentation. The mass that did not undergo conversion to bioethanol ranged from $269.04 \mathrm{~kg}$ to $309.50 \mathrm{~kg}$, which represented $32.07 \%$ to $36.95 \%$ of the organic matter that was subjected to the process of bioethanol production. On that basis, it was concluded that only two-thirds of the organic matter was converted into bioethanol. The remaining part-post-production waste in the form of stillage- became a valuable raw material for the production of biogas, containing one-third of the biodegradable fraction. Under laboratory conditions, between $30.5 \mathrm{~m}^{3}$ (QU-I) and $35.6 \mathrm{~m}^{3}$ (QU-II) of biogas per $1 \mathrm{Mg}$ of FM (FM-fresh matter) was obtained, while under operating conditions, between $29.2 \mathrm{~m}^{3}$ (QU-I) and $33.2 \mathrm{~m}^{3}$ (QU-II) of biogas was acquired from $1 \mathrm{Mg}$ of FM. The Biochemical Methane Potential Correction Coefficient (BMPCC), which was calculated based on the authors' formula, ranged from $3.2 \%$ to $7.4 \%$ in the analysed biogas installation.
\end{abstract}

Keywords: bioethanol; stillage; biogas; biomass conversion degree; biochemical methane potential correction coefficient (BMPCC)

\section{Introduction}

At the moment, energy carriers used for transport are mainly derived from oil. This leads to a reduction in natural fuel resources and the emission of greenhouse gases in significant quantities [1-4]. Europe aims to be the first climate-neutral continent by making its economy modern and resource-efficient. For that reason, the European Union has been supporting the development of renewable energy sources, including biofuels, wind, water, and solar energy, for many years [5]. The biofuel economy in Poland has been in development since around 2000. Ethanol and esters have similar properties to commonly used fuels 
(ethanol and biodiesel), but the major difference between biofuels and petroleum-based fuels lies in the content of oxygen [6]. Biofuels contain 10-45\% oxygen by weight, whereas petroleum-based fuels have basically no oxygen, meaning that biofuel molecules have fewer carbon atoms than those of petroleum, which makes them less calorific. Naturally, liquid biofuels have a higher oxygen content, due to their chemical structure-they are esters of alcohols and higher fatty acids [7]. According to the scientific papers, this difference can be regarded as the most significant. Two liquid biofuels are currently in use in Poland: (i) ethanol, which can substitute petrol; and (ii) biodiesel, used as a diesel additive. Five per cent of ethanol is added to petrol and seven per cent of methyl esters are added to diesel. This is related to the promotion of renewable energy sources and to the reduction in carbon dioxide emissions from fossil fuels, which negatively affect the environment. Emitted into the atmosphere, carbon dioxide is responsible for exacerbating the global greenhouse effect [8].

In Poland, the main raw material for the production of ethanol for energy purposes is maize grains. The maize grown nowadays is one of the most efficient crops in the world. Its yield is associated with many factors, the most important of which include weather patterns, crop variety, growing position, and agrotechnical treatment $[9,10]$. The vegetation period has a major impact on potential yield. In Poland, there are three vegetation period groups described by the FAO number (Food and Agriculture Organization of the United Nations), which is the international index of the development of maize varieties. In Poland, the FAO number for maize varieties is determined by the Research Centre for Cultivar Testing (COBORU). These vegetation period groups are as follows: medium-late (FAO above 260), medium-early (FAO 240-250), and early (FAO up to 230). According to official COBORU data, in 2019-2020 early grain maize varieties yielded an average of 100.0 [dt-ha ${ }^{-1}$ ] (14\% of humidity); mid-early varieties yielded an average of 99.9 [dt-ha $\left.{ }^{-1}\right]$ (14\% of humidity); and mid-late varieties yielded around 100.1 [dt-ha ${ }^{-1}$ ] (14\% of humidity). The average yield from the three varieties of vegetation periods is $99.98\left[\mathrm{dt}^{-h a^{-1}}\right]$, which equals $9.998\left[\mathrm{Mg} \cdot \mathrm{ha}^{-1}\right]$. As a plant, maize has many applications. It is used as animal feed, for the production of biofuel (as already mentioned), and sweetcorn is grown for human consumption. In biofuel production, the whole plant (in the form of maize silage) can be utilised in biogas production processes, and maize grains alone can be used in technologies for obtaining ethanol [11,12]. Maize ears, stalks, and leaves can be processed into fermentable sugars through cellulose-processing technology, which involves pretreatment, hydrolysis, and fermentation involving yeast or other microorganisms. As opposed to cereal feedstocks, the production of cellulose-based ethanol requires microorganisms capable of synthesising ethanol from both glucose and xylose. Maize grains contain large amounts of starch, which is easily converted to monosaccharides after pretreatment (i.e., cooking in water) and the hydrolysis process [13]. The process of producing ethanol from maize has already been consolidated in various countries. The inclusion of this feedstock into the system of production, as pointed out by Brazilian researchers, will add value to the product and contribute to the stabilisation of the ethanol supply in the country [14].

\subsection{Maize Ethanol Production}

The production of ethanol from maize involves the decomposition of the starch contained in maize grains to glucose $\left(\mathrm{C}_{6} \mathrm{H}_{12} \mathrm{O}_{6}\right)$ and maltose $\left(\mathrm{C}_{12} \mathrm{H}_{22} \mathrm{O}_{11}\right)$. Subsequently, both sugars are broken down through alcoholic fermentation to ethanol (see Equation (1)). Starch is a chemical compound consisting exclusively of glucose structural units linked by $\alpha$-glycosidic bonds and hydrolyses only into $\alpha$-D-glucose. However, it is not a chemically homogeneous compound-it consists of two polymeric fractions: branched chains of amylopectin, containing $\alpha-1,4$ and $\alpha-1,6$-glycosidic bonds, and a linear polymer with $\alpha-1,4$-glycosidic bonds of amylose [14]. During the process of ethanol production, the starch structure is destroyed by enzymes and high temperatures. Even though starch exhibits hydrophobic properties, it dissolves in water when heated, which results in the weakening of the hydrogen bonds. As a result, the starch increases in volume; this stage 
is known as the gelation process. Due to the heat treatment and the enzymes involved, the starch decomposes into glucose. At the first stage (hydrolysis), $\alpha$-amylase reduces the polymer chains of starch to dextrins; this process is called liquefaction. The dextrins are then degraded (saccharified) to glucose and maltose in the presence of the glucosamine enzyme [15]. The resulting product is subjected to alcoholic fermentation, resulting in the extraction of ethanol and a by-product, the digestate pulp, which contains chemical compounds that will not convert to ethanol.

Equation (1) illustrates the starch decomposition reaction in the alcoholic fermentation process [16]:

$$
3 \mathrm{C}_{6} \mathrm{H}_{10} \mathrm{O}_{5}+3 \mathrm{H}_{2} \mathrm{O} \rightarrow \mathrm{C}_{6} \mathrm{H}_{12} \mathrm{O}_{6}+\mathrm{C}_{12} \mathrm{H}_{22} \mathrm{O}_{11}+\mathrm{H}_{2} \mathrm{O} \rightarrow 6 \mathrm{C}_{2} \mathrm{H}_{5} \mathrm{OH}+6 \mathrm{CO}_{2}
$$

When it comes to ethanol production, the by-product is stillage, which constitutes a problematic waste product. This material can be used as a substrate for the production of biogas in the process of methane fermentation. Both worldwide and in Poland, there are installations in which ethanol is produced and the digestate is used as a substrate in a biogas plant. Such solutions result in the optimal use of the energy potential of maize grain fuel to produce the maximum number of energy carriers from renewable energy sources.

\subsection{Biogas Production}

Anaerobic technologies have considerable potential in the management of a wide range of organic wastes [17-19]. These wastes most often include waste from animal production, such as manure and slurry, and purpose-grown crops, mainly maize for silage production, but also sewage sludge and food-industry waste [20-22]. In the absence of oxygen, gas is generated from organic biomass containing proteins, fats, and sugars [23]. This gas is defined as biogas due to its origin and generation process, determined by the activity of living micro-organisms. Its main components include methane and carbon dioxide, together accounting for about $95-99 \%$ of the mixture [24,25]. Other gases, contained in biogas in small quantities, include hydrogen, ammonia, and hydrogen sulphide. Biogas can be continuously generated under suitable environmental conditions that are friendly to the perpetual recreation of the methane-forming bacterial flora. Its composition and quantity depend on the parameters of the environment in which it is produced [26,27]. Essentially, the anaerobic digestion process can be divided into four phases: hydrolysis, acidogenesis, acetogenesis, and methanogenesis. A characteristic group of microorganisms, requiring specific environmental conditions, are responsible for each respective cycle [28,29]. This process is usually conducted in a one- or two-stage system involving two fermentation tanks. To conduct anaerobic digestion effectively and maximise the production potential of individual bacterial groups, it is necessary to prepare appropriate feed material and environmental conditions [30-32]. During the production of energy carriers from renewable sources, it is worth introducing integrated technologies to improve the efficiency of biomass conversion from the organic matter contained in it.

The stillage obtained in ethanol plants can be further processed in biogas plants because it contains a certain amount of organic matter from which biogas can be generated (see Figure 1). The aforementioned material contains compounds-mainly lignocelluloses, which can serve as a raw material for the production of biogas through anaerobic digestion [33]. Therefore, the waste product from the first process (stillage) can function as the raw material for a second process (the production of biogas). In their study, Lanzerstorfer and Jäger (2008) identified three main correlations between the processes of bioethanol and biogas production: (i) low-temperature energy is used for heating purposes in the production of bioethanol at the fermentation stage, (ii) high-temperature energy from the cogeneration of waste gas is used to produce steam for the distillation stage in bioethanol production, and (iii) the distillery stillage is used as a raw material for biogas production [34]. However, the industrial-scale application of this solution is often considered groundless, due to its low economic competitiveness in comparison with the production of energy from fossil fuels. These limitations are based on the high-energy requirements 
associated with the treatment of biomass before the fermentation stage and with the management of stillage. In their study, Cesaro and Belgiorno (2015) regarded the combination of bioethanol production and anaerobic digestion as a valuable option that can overcome any limitations, such as those related to the pretreatment of biomass or the management of stillage [35]. Furthermore, the experimental results obtained by the authors revealed that fermentation acts as a pre-treatment of the biomass so that the energy needed to convert stillage into biogas in the anaerobic digestion process is lower than the energy needed to process the entire substrate. It has been unambiguously established that a synergistic combination of alcoholic fermentation and anaerobic digestion can enable the production of ethanol together with biogas, which can be used to produce heat and electricity (see Figure 1-cogeneration aggregate), thus improving the overall energy balance. Martin et al. also draw similar conclusions in their publication (2014) [36]. The findings of the studies conducted within this concept demonstrate how important it is to understand the impact of biofuel production and industrial symbiosis and how valuable the different flows of matter and energy are. The concept of utilising waste biomass in a sequential combination of two biochemical processes, ethanol fermentation and methane fermentation, can also offer specific environmental protection benefits, such as the utilisation of waste from the agricultural sector, a reduction in organic contaminants, and a reduction in dust and gas emissions from the combustion of conventional energy sources [37]. It is rightly assumed that symbiotic activities can lead to benefits regarding environmental performance, although the choice of impact category and allocation method is crucial when comparing local versus global impacts [36].

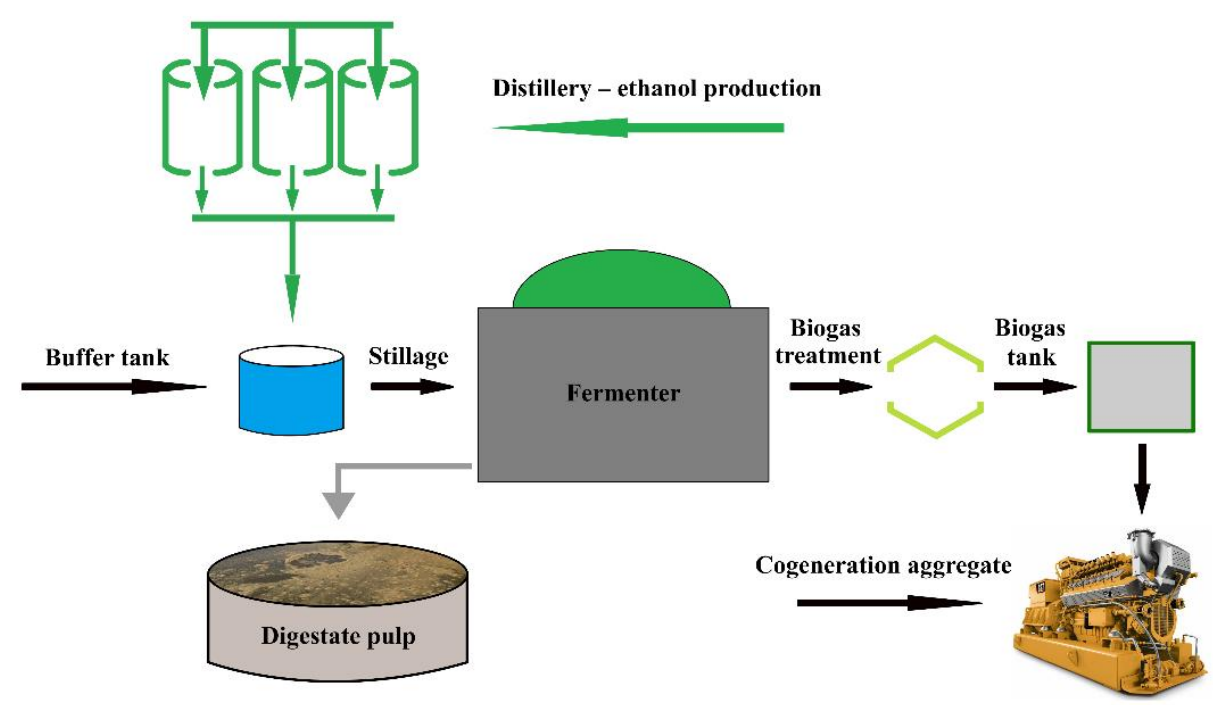

Figure 1. Conceptual scheme of integrated bioethanol and biogas production (authors' own scheme).

This study aimed to determine the energy potential of biomass used for bioethanol and biogas production. Based on the results obtained, the conversion rate of biomass-maize in this case-into bioethanol was determined as the efficiency of the bioethanol production process. At the next stage, it was possible to identify the unused biomass energy potential accumulated in the waste material in the form of stillage. The degree of the conversion of biomass to bioethanol and the susceptibility of biomass to conversion into biogas was therefore determined. The possibility to estimate the insufficient conversion of biomass allows the production of energy carriers from renewable raw materials to be optimised.

\section{Materials and Methods}

\subsection{Physicochemical Analysis of Materials}

Physicochemical analyses of substrates and samples were performed with the use of the methods and procedures described in the following standards: $\mathrm{pH}-$ potentiometric analysis, with Elmetron CP-215, Zabrze, Poland (PN-EN 12176:2004); total solids (residue 
after drying) — gravimetric analysis, measurement by drying at $105^{\circ} \mathrm{C}$ (Zalmed SML dryer, Zalmed, Łomianki, Poland), PN-EN 12880: 2004; volatile solids (residue after roasting) gravimetric analysis, measurement by combustion at $550{ }^{\circ} \mathrm{C}$ (MS Spectrum PAF 110/6 furnace, MS Spectrum, Warsaw, Poland), PN-EN 12879:2004; sample collection for chemical and physical tests, PN-EN ISO 5667-13:2011; carbon, EN ISO 16948:2015; hydrogen, EN ISO 16948:2015; nitrogen, EN ISO 16948:2015; oxygen, based on calculations; sulphur, PN-EN ISO 11885:2009.

The quantitative determination of the chemical composition of maize grains, i.e., starch, total dietary fibre, mineral matter (insoluble ash), fat, and protein was performed according to the following procedures:

- Starch-Luff-Schoorl titration method, range: $(0.50-80) \%$; reduction in $\mathrm{Cu}$ (II) ions in the Luff solution (sodium carbonate, citric acid, copper sulphate) by reducing sugars, boiling point, $\mathrm{pH}$ approx. 9.5 [38];

- Fibre - chemical method (fibre is determined as the fraction remaining after digestion with standard solutions of $0.25 \mathrm{~N}$ sulphuric acid and $0.25 \mathrm{~N}$ sodium hydroxide under carefully controlled conditions) AOAC 962.09 [39];

- Fat-Soxhlet method, extracted with hexane using a Soxhlet automatic extractor, model B-811 BUCHI, (Büchi Labortechnik AG, Flawil, Switzerland); AOAC 920.85 [40];

- Protein-calculated from TKN (total Kjeldahl nitrogen) using a conversion factor of 6.25 for crude proteins; AOAC 920.87 [41]; TKN—titration, Kjeldahl method, $0.1 \mathrm{n} \mathrm{HCl}$, Tashiro's indicator; PN-EN 13342, EN 15104:2011;

- Mineral matter-ash, range: (0.02-40\%), gravimetric analysis [42].

To determine the elemental composition of maize grains, the elemental analysis of elements $\mathrm{C}, \mathrm{H}, \mathrm{N}, \mathrm{S}$, and $\mathrm{O}$ was performed using the CHNSO FlashSmart series elemental analyser obtained from Thermo Fisher Scientific (Waltham, MA, USA), which is Organic Elemental Analysis (OEA) equipment. The device uses the method of the dynamic combustion of samples (of both organic and inorganic origin) in a reactor filled with an oxidation-reduction catalytic bed, with the electronically controlled temperature reaching 1800 degrees Celsius (CHNS analyses) or in a pyrolytic reactor (O analyses). The analyser works by separating combustion gases on a chromatographic pillar and then detecting them on a highly sensitive thermoconductivity detector.

\subsection{Laboratory Scale}

The anaerobic digestion process was conducted in a periodic mode of operation of the digesters, under mesophilic conditions. The authors of this study presented a detailed diagram and described the design and operation of biodigesters in their previous publications (Figure 2) [43,44].

According to the German standard DIN Guideline 38 414-S8 (DIN, Deutsches Institut für Normung) [45], the experiment was conducted until the daily biogas production in all biofermenters decreased below $1 \%$ of the total biogas production. The volume of biogas, which was generated using the laboratory scale from stillage, was measured every $24 \mathrm{~h}$. The concentrations of methane, carbon dioxide, hydrogen sulphide, ammonia, and oxygen in the biogas were measured using a Geotech GA5000 gas analyser (Geotech, Bydgoszcz, Poland).

The estimation of the biogas efficiency (in $\mathrm{m}^{3} \cdot \mathrm{Mg}^{-1}$ ) from dry matter or dry organic matter was based on experimental data. The biogas efficiency for a given substrate was determined by subtracting the amount of biogas produced from the inoculum alone (obtained in the control test) from the amount of biogas produced for the mixture (substrate/inoculum). For bioreactors with a substrate or mixture of substrates tested, the cumulative amount of biogas produced from the inoculum (digested sewage sludge) was calculated based on the corresponding equation presented in other publications of the authors [21-24]. Specific biogas production from the substrate (dependent on the duration of the test) was calculated in stages-from one reading to another [21-24]. 


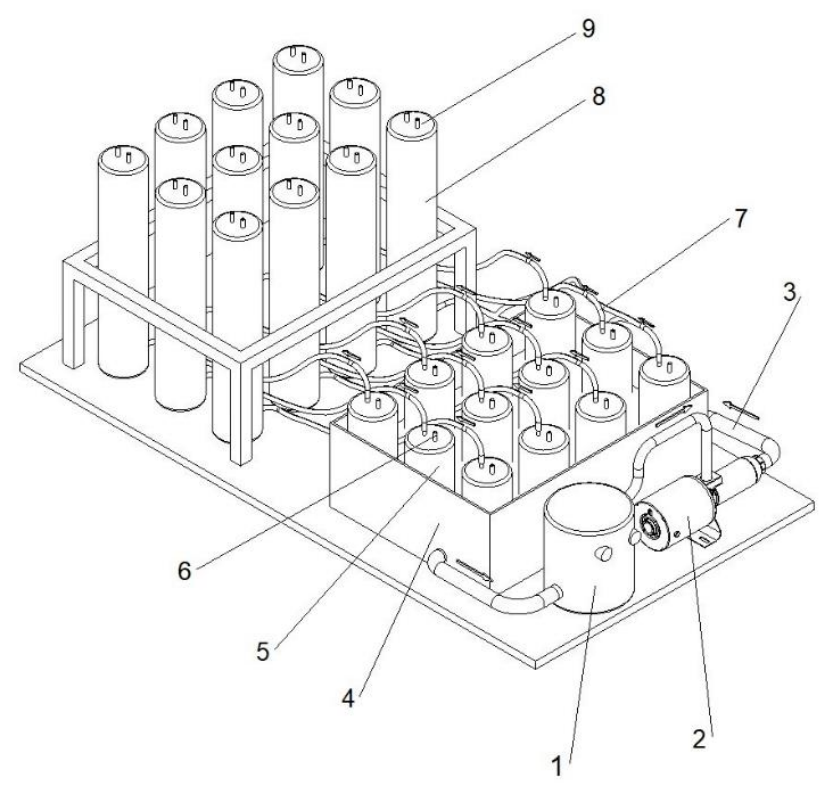

Figure 2. Anaerobic bioreactor used in biogas production experiment: 1 -water heater; 2 -water pump; 3-insulated tubes for heating medium; 4-water jacket $\left(39^{\circ} \mathrm{C}\right)$; 5 -bioreactor $(1.4 \mathrm{~L})$; 6-slurry sampling valve; 7-tube for biogas transport; 8-graduated tank for biogas; 9-gas sampling valve (authors' own elaboration).

\subsection{Construction and Operation of an Industrial Installation}

The biomass conversion study was conducted for 12 months in a biogas plant that used stillage derived from bioethanol produced in a Polish distillery (the exact location is not given at the request of the owner). Stillage samples were collected at quarterly intervals for accurate stillage analysis. The biogas plant (also in Poland) consisted of 2 digesters and a lagoon for digestate. The anaerobic digestion process was conducted simultaneously in both tanks, without division into primary and secondary digestion. The installation was equipped with a 1 MWe cogeneration plant.

\subsection{Collection of Samples for Tests}

Samples for testing both maize grains and the stillage were collected every quarter (QU-I, QU-II, QU-III, QU-IV; QU—quarter). During sample collection, the following points were taken into account: the accessibility of the sampling point, the possibility of a safe interruption of the material flow in case of manual sampling, and the type of digester design due to the stratification of the test material. In addition, the safest and most practical position for manual sampling was analysed and the practicality of the location of the sampling site was considered due to the crucial role and representativeness of the material collected for testing. At least 3 samples were collected and tested each time to increase confidence in the representativeness of the material collected. The material analysed for representativeness was then subjected to testing. Based on the analyses performed, the uncertainty of the results was also determined.

Measurement uncertainty is a component of the individual stages of the analytical procedure. Uncertainty is a fundamental property of any measurement and it is encountered at every stage of the measurement procedure. The measurement uncertainty estimation in this study employed procedures in line with standards and literature data $[46,47]$.

\subsection{Determination of the Biochemical Methane Potential Correction Coefficient (BMPCC)}

Due to the lack of reliable data in the source literature regarding biomass conversion on a technical scale, the authors developed and applied the Biochemical Methane Potential Correction Coefficient (BMPCC) in their previous paper [48]. The coefficient can be used to verify the operation of the installation in terms of the decomposition of organic matter 
into methane as compared to laboratory conditions. With the application of chemical formulae and laboratory tests, the potential amount of methane from the substrate can be determined, allowing for a more accurate analysis of the installation's efficiency on a technical scale. Consequently, this parameter acts as a diagnostic tool for a biogas installation over a specific time interval.

To calculate the BMPCC, it is necessary to determine the values of relevant parameters, according to the coefficient formula (Equation (4)). In the first phase, the amount of biogas obtained from the substrate $\left(\mathrm{m}^{3} \cdot \mathrm{Mg}^{-1}\right.$ fresh matter (FM)) was estimated in the laboratory [43]. At the same time, the biogas composition was analysed in order to determine the $\mathrm{CH}_{4}$ and $\mathrm{CO}_{2}$ concentrations. After determining the composition of the biogas, the process proceeded to the calculation of the volume of methane. Subsequently, the mass of methane contained in the biogas was determined under laboratory conditions (mass of methane in biogas obtained from fresh substrate matter under laboratory conditions, MMB-L; L-laboratory). The third stage involved the analysis of the substrate for dry residue, roasting losses, and the content of carbon, hydrogen, oxygen, nitrogen, and sulphur. Once the content of $\mathrm{C}, \mathrm{H}, \mathrm{O}, \mathrm{N}$ and $\mathrm{S}$ was determined, the theoretically obtainable amount of methane (theoretical methane mass, TMM) was calculated according to the principle of mass conservation. It was followed by the fourth stage, in which the conversion of organic matter contained in biomass under laboratory conditions was calculated (conversion of organic matter under laboratory conditions-laboratory biomass conversion degree, COM-L). Equation (2) is as follows [48]:

$$
\mathrm{COM}-\mathrm{L}=\frac{\mathrm{MMB}-\mathrm{L}}{\mathrm{TMM}}
$$

The next stage involved the calculation of the conversion of organic matter contained in the biomass under the operating conditions of the installation (conversion of organic matter in the installation-industrial biomass conversion stage, COM-I; I-industrial) [41]. Equation (3) is as follows [48]:

$$
\mathrm{COM}-\mathrm{I}=\frac{\mathrm{MMB}-\mathrm{I}}{\mathrm{TMM}}
$$

The final stage of the process was to calculate the BMPCC of each substrate as the ratio of the mass of methane produced in the installation to the mass of methane produced under laboratory conditions. Equation (4) is as follows [48]:

$$
\mathrm{BMPCC}=100-\frac{\mathrm{COM}-\mathrm{I}}{\mathrm{COM}-\mathrm{L}} \times 100
$$

\section{Results and Discussion}

\subsection{Elemental Analysis of Maize Grains}

The starting point for the calculations made in this study was the analysis of the percentage content of chemical compounds in the maize grain, which acts as a substrate in a distillery (see Figure 3). Grain analysis was performed quarterly; four consecutive periods yielded very similar grain chemistry results, allowing them to be averaged. For the values shown in Figure 3, the uncertainties of the results were \pm 1.9 for starch, \pm 0.34 for fibre, \pm 0.042 for mineral matter, \pm 0.21 for fat, and \pm 0.24 for protein (amino acids).

Next, based on the elemental analyses of the maize grain sampled in each quarter, the elementary formulae were determined, and are presented in Table 1.

Table 2 shows the molar mass of the individual elements that constitute the chemical compounds that make up the maize grain and the intermediate compounds in the alcoholic fermentation process (glucose and maltose). The presented data show that the C:H:O ratio is similar. 


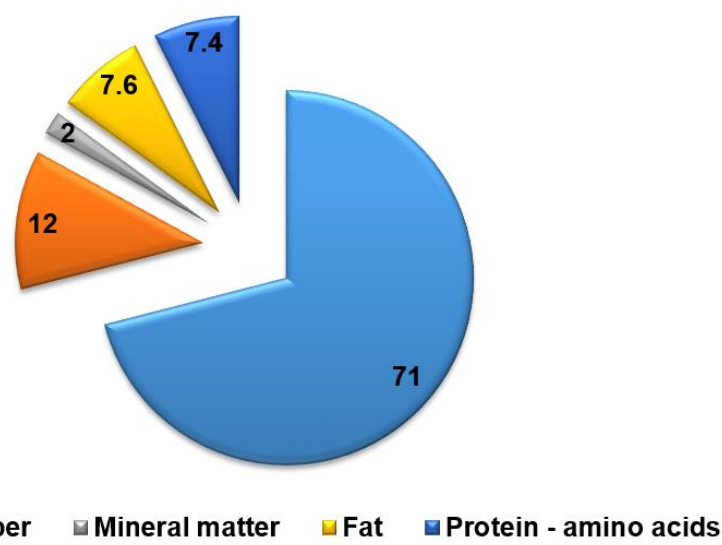

Figure 3. Chemical composition of maize grain (authors' own elaboration).

Table 1. Content of individual elements in the molecules of the maize grain sampled in each quarter, determined by elemental analysis.

\begin{tabular}{cc}
\hline Sample & Elementary Formula of Maize Grain \\
\hline QU-I & $\mathrm{C}_{7.178} \mathrm{O}_{12.123} \mathrm{H}_{4.266} \mathrm{~N}_{0.130} \mathrm{~S}_{0.074}$ \\
QU-II & $\mathrm{C}_{7.218} \mathrm{O}_{12.126} \mathrm{H}_{4.246} \mathrm{~N}_{0.130} \mathrm{~S}_{0.074}$ \\
QU-III & $\mathrm{C}_{7.143} \mathrm{O}_{12.057} \mathrm{H}_{4,258} \mathrm{~N}_{0.129} \mathrm{~S}_{0.071}$ \\
QU-IV & $\mathrm{C}_{7.212} \mathrm{O}_{12.138} \mathrm{H}_{4.222} \mathrm{~N}_{0.136} \mathrm{~S}_{0.078}$ \\
\hline Explanations: QU-quarter; C—carbon; O—oxygen; H-hydrogen; $\mathrm{N}$ - nitrogen; S- - sulphur.
\end{tabular}

Table 2. Molar mass of individual elements and of starch, glucose, maltose, and maize grain sampled in each quarter.

\begin{tabular}{|c|c|c|c|c|c|c|}
\hline \multicolumn{7}{|c|}{ Molar Mass (g. mol-1) } \\
\hline Element. Formula & $\mathrm{C}$ & $\mathbf{H}$ & $\mathbf{O}$ & $\mathbf{N}$ & $S$ & Compounds \\
\hline Starch, $\mathrm{C}_{6} \mathrm{H}_{10} \mathrm{O}_{5}$ & 72.07 & 10.08 & 80.00 & - & - & 162.15 \\
\hline Glucose, $\mathrm{C}_{6} \mathrm{H}_{12} \mathrm{O}_{6}$ & 72.07 & 12.10 & 96.00 & - & - & 180.17 \\
\hline Maltose, $\mathrm{C}_{12} \mathrm{H}_{22} \mathrm{O}_{11}$ & 144.13 & 22.18 & 176.00 & - & - & 342.31 \\
\hline $\begin{array}{c}\text { QU-I } \\
\mathrm{C}_{7.178} \mathrm{O}_{12.123} \mathrm{H}_{4.266} \mathrm{~N}_{0.130} \mathrm{~S}_{0.074}\end{array}$ & 86.14 & 12.13 & 68.26 & 1.82 & 2.37 & 171.71 \\
\hline $\begin{array}{c}\text { QU-II } \\
\mathrm{C}_{7.218} \mathrm{O}_{12.126} \mathrm{H}_{4.246} \mathrm{~N}_{0.130} \mathrm{~S}_{0.074}\end{array}$ & 86.62 & 12.15 & 67.82 & 1.82 & 2.37 & 170.89 \\
\hline $\begin{array}{c}\text { QU-III } \\
\mathrm{C}_{7.143} \mathrm{O}_{12.057} \mathrm{H}_{4,258} \mathrm{~N}_{0.129} \mathrm{~S}_{0.071}\end{array}$ & 85.72 & 12.06 & 68.13 & 1.81 & 2.27 & 169.98 \\
\hline $\begin{array}{c}\text { QU-IV } \\
\mathrm{C}_{7.212} \mathrm{O}_{12.138} \mathrm{H}_{4.222} \mathrm{~N}_{0.136} \mathrm{~S}_{0.078}\end{array}$ & 86.54 & 12.14 & 67.55 & 1.90 & 2.50 & 170.63 \\
\hline
\end{tabular}

Explanations: element. Formula—elementary formula; QU—quarter; chem.—chemical; C—carbon; O—oxygen; H—hydrogen; Nnitrogen; S-sulphur.

\subsection{Volume of Ethanol Obtained from One Tonne of Maize Grain in the Analysed Installation}

According to different authors, between 340 and $410 \mathrm{~L}$ of ethanol can be obtained from $1 \mathrm{Mg}$ of maize grain [49,50]. In the analysed installation, which is located in Poland, one $\mathrm{Mg}$ of maize grain yielded, as shown in Table 3, between 342 (QU-II) and 370 (QU-I) litres of ethanol, expressed by $100 \%$ ethanol of $0.7893 \mathrm{~g} \cdot \mathrm{mL}^{-1}$ density, which confirms the literature data $[51,52]$.

According to Milanez et al. [53], the cycle of corn production is four months long, has the advantage of storing grain, and also off-season maize production. As noted by Quintera et al., (2008), compared to sugarcane ethanol, corn ethanol has some manufacturing defects, but corn uses less water ( $\mathrm{mm}$ ) in its harvest cycle, and the harvesting cost is lower [54] In addition, maize grains contain more starch than, for example, potatoes or rye [55,56]. Regarded as the greatest energy source in cereals [57], for this reason, corn is the primary material in Poland for the production of ethanol for energy purposes. Amylose 
(15-25\%) and amylopectin (75-85\%) are the two polysaccharides that comprise starch [58]. Amylose is essentially linear and made up of D-glucose molecules of alpha-1,4 bonds, whereas amylopectin is a highly branched macromolecule consisting of short chains of D-glucose with alpha-1,4 bonds and 1,6 branching points. Corn starch contains approximately 25-28\% amylose, which affects the structural characteristics of the starch-due to the linearity of its chemical chain, it ensures granule resistance [59].

Table 3. Volume of pure ethanol obtained from the analysed maize in each quarter.

\begin{tabular}{|c|c|c|}
\hline Sample & $\begin{array}{l}\text { Volume of Ethanol Obtained } \\
\qquad\left(\mathrm{dm}^{3} \cdot \mathrm{Mg}_{\mathrm{FM}}{ }^{-1}\right)\end{array}$ & $\begin{array}{l}\text { Mass of Ethanol Obtained } \\
\left(\mathrm{kg} \cdot \mathrm{Mg}_{\mathrm{FM}}{ }^{-1}\right)\end{array}$ \\
\hline QU-I & 370 & 292.04 \\
\hline QU-II & 342 & 279.94 \\
\hline QU-III & 356 & 280.99 \\
\hline QU-IV & 364 & 287.31 \\
\hline
\end{tabular}

Explanations: QU—quarter; FM—fresh matter; Mg—-megagram (tonne, $\mathrm{t}$ ).

Table 4 shows the basic parameters of the maize grain samples for each quarter. According to the data, throughout the entire study period, the percentage content of total solids was similar and ranged between $84.9 \%$ for QU-IV and $86.2 \%$ for QU-I. The value of volatile solids was also similar for individual samples and ranged between $97.9 \%$ for QU-IV and 98.6\% for QU-III.

Table 4. Parameters of the analysed maize grain sampled in subsequent quarters.

\begin{tabular}{ccccc}
\hline Sample & $\begin{array}{c}\text { Total Solids } \\
(\mathbf{\%})\end{array}$ & $\begin{array}{c}\text { Measurement Uncertainty } \\
( \pm \mathbf{)}\end{array}$ & $\begin{array}{c}\text { Volatile Solids } \\
\mathbf{( \% )}\end{array}$ & $\begin{array}{c}\text { Measurement Uncertainty } \\
( \pm \mathbf{)}\end{array}$ \\
\hline QU-I & 86.2 & 1.88 & 98.4 & 2.20 \\
QU-II & 85.3 & 1.86 & 98.2 & 2.20 \\
QU-III & 85.8 & 1.87 & 98.6 & 2.21 \\
QU-IV & 84.9 & 1.85 & 97.9 & 2.19 \\
\hline
\end{tabular}

Table 5 shows the percentage content of elements in relation to their mass in each molecule. The highest carbon content was found in maize grain (from quarters QU-I, QU-II, QU-III, and QU-IV) due to the presence of lignin, fat, and protein. On the other hand, as shown in Table 5, the grain contains proportionally fewer oxygen atoms per molecule compared to starch. Starch in maize grain breaks down into glucose and maltose during the process of alcoholic fermentation. In contrast, the other compounds are inert and do not participate directly in the process. However, because of temperature (mainly lignin) and some random processes, particularly those that disrupt the alcoholic fermentation process, their structure can be completely or partially destroyed due to the activity of competing microorganisms. In the process of obtaining ethanol, the chemical compounds that do not participate in the process penetrate the stillage and provide a potential source of energy for subsequent stages of biomass utilisation. The results presented in Table 5 are juxtaposed to illustrate the energy potential of maize grain as compared to starch as the main chemical compound responsible for the alcoholic fermentation process efficiency.

Table 5. Percentage (mass) content of individual elements in $1 \mathrm{Mg}$ of maize grain as derived from the elementary formula.

\begin{tabular}{|c|c|c|c|c|c|}
\hline Element. Formula & $\begin{array}{c}C \\
(\%)\end{array}$ & $\begin{array}{c}\mathbf{H} \\
(\%)\end{array}$ & $\begin{array}{c}\mathrm{O} \\
(\%)\end{array}$ & $\begin{array}{c}\mathrm{N} \\
(\%)\end{array}$ & $\begin{array}{c}S \\
(\%)\end{array}$ \\
\hline Starch, $\mathrm{C}_{6} \mathrm{H}_{10} \mathrm{O}_{5}$ & 44.44 & 6.17 & 49.38 & - & - \\
\hline Glucose, $\mathrm{C}_{6} \mathrm{H}_{12} \mathrm{O}_{6}$ & 40.00 & 6.67 & 53.33 & - & - \\
\hline Maltose, $\mathrm{C}_{12} \mathrm{H}_{22} \mathrm{O}_{11}$ & 42.11 & 6.43 & 51.46 & - & - \\
\hline $\begin{array}{c}\text { QU-I } \\
\mathrm{C}_{7.178} \mathrm{O}_{12.123} \mathrm{H}_{4.266} \mathrm{~N}_{0.130} \mathrm{~S}_{0.074}\end{array}$ & 50.46 & 7.10 & 39.98 & 1.07 & 1.39 \\
\hline
\end{tabular}


Table 5. Cont.

\begin{tabular}{cccccc}
\hline Element & $\begin{array}{c}\mathbf{C} \\
(\%)\end{array}$ & $\begin{array}{c}\mathbf{H} \\
\mathbf{( \% )}\end{array}$ & $\begin{array}{c}\mathbf{O} \\
\mathbf{( \% )}\end{array}$ & $\begin{array}{c}\mathbf{N} \\
\mathbf{( \% )}\end{array}$ & $\begin{array}{c}\mathbf{S} \\
\mathbf{( \% )}\end{array}$ \\
\hline $\begin{array}{c}\text { QU-II } \\
\mathrm{C}_{7.218} \mathrm{O}_{12.126} \mathrm{H}_{4.246} \mathrm{~N}_{0.130} \mathrm{~S}_{0.074} \\
\text { QU-III }\end{array}$ & 50.69 & 7.11 & 39.76 & 1.07 & 1.39 \\
$\begin{array}{c}\mathrm{C}_{7.143} \mathrm{O}_{12.057} \mathrm{H}_{4,258} \mathrm{~N}_{0.129} \mathrm{~S}_{0.071} \\
\text { QU-IV } \\
\mathrm{C}_{7.212} \mathrm{O}_{12.138} \mathrm{H}_{4.222} \mathrm{~N}_{0.136} \mathrm{~S}_{0.078}\end{array}$ & 50.43 & 7.09 & 40.08 & 1.06 & 1.34 \\
\hline
\end{tabular}

Explanations: element. formula—elementary formula; $\mathrm{QU} —$ quarter; chem.—chemical; $\mathrm{C}-$ carbon; $\mathrm{O}-\mathrm{oxygen}$; $\mathrm{H}-$ hydrogen; $\mathrm{N}-$ nitrogen; S-sulphur.

The average yield of pure $100 \%$ ethanol from an $\mathrm{Mg}$ of maize grain can be used to determine how much organic matter was converted into ethanol. Table 6 presents the conversion of organic matter subjected to alcoholic fermentation, including a calculation of the mass of each chemical compound.

Table 6. Conversion of organic matter into ethanol and carbon dioxide.

\begin{tabular}{|c|c|c|c|c|c|}
\hline Sample & $\begin{array}{c}\text { Ethanol } \\
\mathrm{C}_{2} \mathrm{H}_{5} \mathrm{OH} \\
(\mathrm{kg})\end{array}$ & $\begin{array}{c}\text { Carbon Dioxide } \\
\mathrm{CO}_{2} \\
(\mathbf{k g})\end{array}$ & $\begin{array}{c}\text { Organic Matter } \\
\text { Converted by } \\
\text { Alcoholic } \\
\text { Fermentation (kg) }\end{array}$ & $\begin{array}{c}\text { Organic Matter Not } \\
\text { Converted by Alcoholic } \\
\text { Fermentation } \\
(\mathbf{k g})\end{array}$ & $\begin{array}{c}\text { Percentage of Organic } \\
\text { Matter Not Converted by } \\
\text { Alcoholic Fermentation } \\
(\%)\end{array}$ \\
\hline QU-I & 292.04 & 279.34 & 571.38 & 276.82 & 32.64 \\
\hline QU-II & 269.94 & 258.20 & 528.14 & 309.50 & 36.95 \\
\hline QU-III & 280.99 & 268.77 & 549.76 & 296.22 & 35.02 \\
\hline QU-IV & 287.31 & 274.82 & 562.13 & 269.04 & 32.37 \\
\hline
\end{tabular}

The conceptual reaction for obtaining ethanol is as follows [60] (Equation (5)):

$$
\mathrm{C}_{6} \mathrm{H}_{12} \mathrm{O}_{6} \rightarrow 2 \mathrm{C}_{2} \mathrm{H}_{5} \mathrm{OH}+2 \mathrm{CO}_{2}
$$

During the alcoholic fermentation process, the starch contained in the maize grain has an overarching impact on the amount of bioethanol obtained [61,62]. Nonetheless, this process can be disrupted by infection with viruses or bacteria that will compete for nourishment with the right microorganisms responsible for the actual process of alcoholic fermentation. The data presented in Table 6 reveal that the most effective bioethanol production process took place in QU-IV, where the percentage of non-converted mass was the lowest, reaching $32.37 \%$. The lowest degree of organic matter reactivity $(528.14 \mathrm{~kg})$ was recorded in QU-II, where the degree of non-reactivity was 36.95\%.

\subsection{Analysis of Digestate Pulp from Bioethanol Production in a Biogas Plant-Tests in the Laboratory and on a Technical Scale}

The stillage derived from the production of bioethanol was subjected to laboratoryscale testing of their biochemical methanogenic potential. For each tonne of maize grain processed, the analysed industrial plant produces an average of $5 \mathrm{~m}^{3}$ of stillage, which is used as a raw material to feed the biogas plant. The capacity of the biogas plant, which remains in research-based cooperation during this experiment, amounts to $1 \mathrm{MW}_{\mathrm{e}}$. Table 7 lists the basic stillage parameters. Figures 4 and 5 present the volume of biogas obtained and the concentration of biogas methane from $1 \mathrm{Mg}$ FM (FM-fresh matter) of the stillage.

Figures 4 and 5 present the results concerning the amount of biogas obtained (Figure 4), including methane (Figure 5), under laboratory and technical conditions. The highest biogas yield was obtained in QU $-\mathrm{n} \mathrm{II}$, exceeding $35.6 \mathrm{~m}^{3} \cdot \mathrm{Mg} \mathrm{FM}^{-1}$ on the laboratory scale and $33.2 \mathrm{~m}^{3} \cdot \mathrm{Mg} \mathrm{FM}^{-1}$ on the technical scale. In contrast, the lowest biogas volumes were obtained in QU-I-in total, $30.5 \mathrm{~m}^{3} \cdot \mathrm{Mg} \mathrm{FM}^{-1}$ was obtained on the laboratory scale and $29.2 \mathrm{~m}^{3} \cdot \mathrm{Mg} \mathrm{FM}^{-1}$ on the technical scale. The methane content in biogas ranged from $50.1 \%$ 
in QU-I to 50.9\% in QU-III. Remarkably similar methane contents in biogas point to a stable anaerobic digestion process and high repeatability of the quality composition of the stillage that was fed in. The differences in the amount of biogas volume obtained, on the other hand, are mainly related to the quality of the alcoholic fermentation process, which directly affects the content of organic matter (in the stillage), which is a nutrient substance for anaerobic digestion bacteria [63]. It serves as the confirmation that these processes function in an integrated manner and remain in industrial symbiosis with each other $[64,65]$ to comprehensively utilise organic matter for energy purposes. A full understanding of the mechanism of this concept provides an opportunity to undertake process optimisation in accordance with the technological principle of using the raw material and the energy stored in it most effectively.

Table 7. Parameters of stillage samples fed to the biogas installation in consecutive quarters.

\begin{tabular}{ccccccc}
\hline Sample & $\mathbf{p H}$ & $\begin{array}{c}\text { Measurement Uncertainty } \\
( \pm \mathbf{)}\end{array}$ & $\begin{array}{c}\text { Total Solids } \\
\mathbf{( \% )}\end{array}$ & $\begin{array}{c}\text { Measurement } \\
\text { Uncertainty }( \pm \mathbf{)}\end{array}$ & $\begin{array}{c}\text { Volatile Solids } \\
\mathbf{( \% )}\end{array}$ & $\begin{array}{c}\text { Measurement Uncertainty } \\
( \pm \mathbf{)}\end{array}$ \\
\hline QU-I & 4.2 & 0.08 & 5.54 & 0.12 & 76.1 & 0.86 \\
QU-II & 4.4 & 0.09 & 6.19 & 0.14 & 78.5 & 0.89 \\
QU-III & 4.3 & 0.08 & 5.92 & 0.13 & 76.8 & 0.87 \\
QU-IV & 4.4 & 0.09 & 5.38 & 0.12 & 77.9 & 0.89 \\
\hline
\end{tabular}

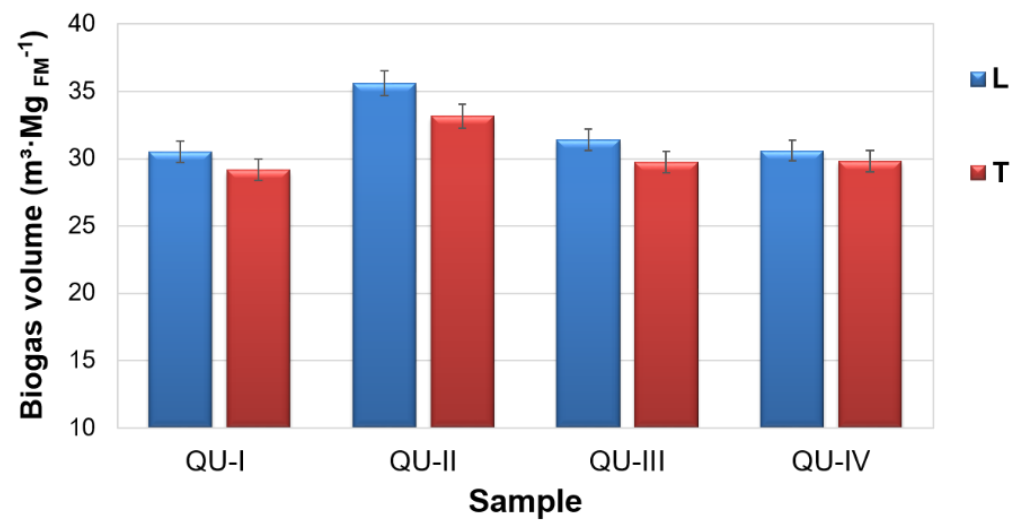

Figure 4. Volume of biogas obtained from $\mathrm{m}^{3} \cdot \mathrm{Mg} \mathrm{FM}^{-1}$ (L-laboratory scale; $\mathrm{T}$-technical scale).

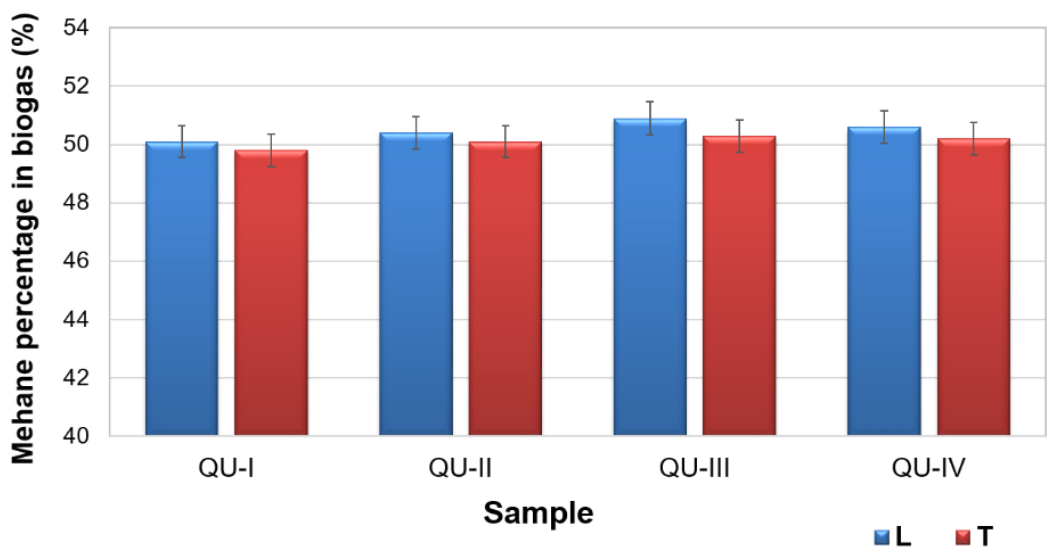

Figure 5. Methane percentage in biogas (L-laboratory scale; $\mathrm{T}$-technical scale).

\subsection{Conversion of the Organic Matter Contained in the Stillage}

Figures 4 and 5 were used to determine the mass of methane in the biogas obtained from the fresh matter of the substrate under laboratory conditions (MMB-L, see Section 2.5). Then, the principle of mass conservation (stoichiometric Equation (6)) was applied to calculate how much methane can theoretically be obtained when the values of $C, H$, 
$\mathrm{O}, \mathrm{N}$, and $\mathrm{S}$ are known, i.e., the theoretical methane mass (TMM) based on elementary chemical formulae.

$$
\mathrm{C}_{\mathrm{c}} \mathrm{H}_{\mathrm{h}} \mathrm{O}_{\mathrm{o}} \mathrm{N}_{\mathrm{n}} \mathrm{S}_{\mathrm{s}}+\mathrm{yH} \mathrm{H}_{2} \mathrm{O} \rightarrow \mathrm{xCH}+(\mathrm{c}-\mathrm{x}) \mathrm{CO}_{2}+\mathrm{nNH}_{3}+\mathrm{sH}_{2} \mathrm{~S}
$$

Further, the conversion of organic matter to methane was determined (see Figure 6) both on the laboratory and technical scales (Equations (2) and (3)). Under laboratory conditions, higher biomass conversion rates were observed for each period compared to the technical scale. The poorest biomass decomposition occurred during QU-III and the best decomposition took place in QU-II and QU-IV under laboratory conditions.

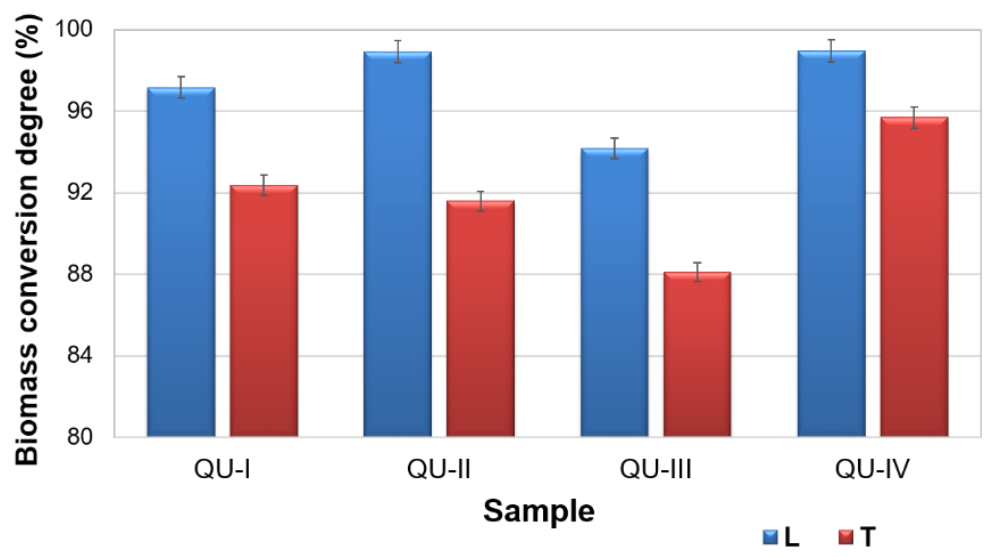

Figure 6. Biomass conversion degree (L-laboratory scale; T—-technical scale).

In the literature on the subject, there is a clear lack of information addressing the underestimation of biomass conversion under actual conditions when compared to laboratory conditions. The lack of knowledge in this regard can have a negative impact on the economic balance of the entire process that is conducted on a real scale. The integrated production of bioethanol and biogas presented in the literature mainly concerns the implementation of processes on a laboratory scale, which, in turn, can only serve as a model $[36,37]$. Only a few publications highlight the fact that hybrid biomass conversion in combined technologies is very much needed and warranted, and they do not explain what this need results from.

Based on the data presented above (Figure 6), it was possible to calculate the Biochemical Methane Potential Correction Coefficient (BMPCC, Equation (4)), the values of which are presented in Figure 7. With the BMPCC, it was possible to identify the quarter in which the anaerobic digestion process on the technical scale deviated from the same process under laboratory conditions. At the same time, information was acquired on the extent to which biomass did not convert. It was found that biomass in QU-II had the weakest degree of degradation, while biomass in QU-IV had the greatest-on the technical scale, as compared to the laboratory scale. As previously mentioned, the BMPCC can serve as a diagnostic parameter to determine the condition of a biogas installation over a specific time interval [48].

In conclusion, the integrated production of bioethanol and biogas is an example of industrial symbiosis - which, taking into account both environmental and economic needs related to the emission of greenhouse gases, the diversification of biofuel production, the creation of conditions for self-sufficiency, and the stimulation of economic developmentpositively influences the efficiency of technological processes (optimisation of materials and energy). It is worth mentioning that there are several examples of the biofuel industry effectively using by-products in further applications, due to their organic makeup. In addition to the previously discussed use of ethanol byproducts for biogas production, other applications include the use of glycerol from biodiesel production for biogas production, the use of digestate from biogas plants as a fertilizer, and the use of sewage treatment 
byproduct (sewage sludge) as a substrate in biogas plants (preferably adjacent to sewage treatment plants) $[21,24,36]$.

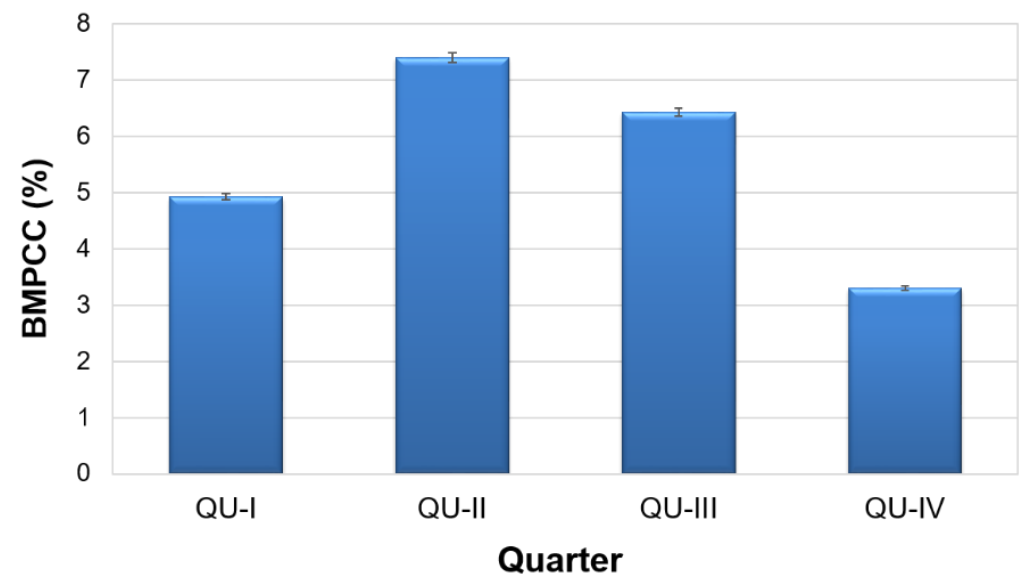

Figure 7. Biochemical Methane Potential Correction Coefficient (BMPCC) for individual quarters.

Publications related to the topic of the integrated production of bioethanol and biogas mainly address: (i) local and global symbiotic activities (potential acidification and eutrophication due to system expansion, and global benefits); (ii) maize pretreatment methods (improving access to cellulose in maize silage and extracting hemicellulose sugars from maize silage fibres by, e.g., steam pretreatment, with or without a catalyst) that increase the efficiency of ethanol production [66,67]; and (iii) applications of new, interesting raw biomaterials for bioethanol and biogas production-such as a species of wild inedible cassava, Manihot glaziovii (tubers obtained from three different areas in Tanzania) [68] - a general evaluation of the efficiency of the process [65,69], and its economic aspects [70]. As previously mentioned, the efficiency scores of the bioethanol production process, including methane, quoted from other papers are comparable to those presented in this study. However, authors have often indicated that higher energy efficiency options (e.g., due to the processing methods applied) did not necessarily result in lower ethanol production costs. Yet, these works lack information addressing the underestimation of biomass conversion under actual conditions when compared to laboratory conditions.

\section{Conclusions}

The integrated production of bioethanol and biogas makes it possible to optimise the production of carriers from renewable raw materials. The organic matter subjected to alcoholic fermentation yielded between $342 \mathrm{~L}$ (QU-II) and $370 \mathrm{~L}$ (QU-I) of ethanol, expressed by $100 \%$ ethanol of $0.7893 \mathrm{~g} \cdot \mathrm{mL}^{-1}$ density. The mass that did not undergo conversion to bioethanol ranged from $269.04 \mathrm{~kg}$ to $309.50 \mathrm{~kg}$, representing $32.07 \%$ to $36.95 \%$ of the organic matter processed to produce bioethanol. With this in mind, it was concluded that only two-thirds of the organic matter was converted into bioethanol. The remaining part, as post-production waste in the form of stillage, became a valuable raw material for the production of biogas, containing one-third of the biodegradable fraction.

The installation analysed in this experimental paper was a hybrid system, in which waste from bioethanol production was used in a biogas plant with a capacity of $1 \mathrm{MW}_{\mathrm{e}}$. Under laboratory conditions, the organic material, derived from stillage and subjected to anaerobic digestion, yielded between $30.5 \mathrm{~m}^{3}$ (QU-I) and $35.6 \mathrm{~m}^{3}$ (QU-II) of biogas per $1 \mathrm{Mg}_{\mathrm{FM}}$. On the other hand, under operating conditions, between $29.2 \mathrm{~m}^{3}$ (QU-I) and $33.2 \mathrm{~m}^{3}$ (QU-II) was obtained from $1 \mathrm{Mg}$ FM, which directly translated to the degree of conversion of biomass to biogas, including methane-the energy carrier. The content of methane in the biogas produced on a technical scale was also lower than under laboratory conditions. For this reason, it is important for biogas plant owners to be able to estimate the insufficient conversion of biomass in their plants. 
The Biochemical Methane Potential Correction Coefficient (BMPCC), which was developed in an earlier paper by the authors, made it possible to determine the difference between the efficiencies of the anaerobic digestion processes occurring in the installation and in the laboratory (as the ratio between the mass of methane produced in the installation and the mass of methane produced under laboratory conditions). With these calculations, it is possible to carry out a thorough analysis of the process implemented in a given plant and obtain clear information on the direction of solutions to improve installation efficiency. In the biogas installation analysed in this paper, the BMPCC ranged between $3.2 \%$ and $7.4 \%$, which is indicative of the efficient conversion of biomass to biogas on a real scale. Biomass subjected to the process of anaerobic digestion is more susceptible to decomposition during anaerobic digestion.

Author Contributions: Conceptualization, K.P. and A.A.P.; methodology, K.P. and A.A.P.; software, P.B.; validation, K.P., G.N. and M.P.; formal analysis, A.A.P.; investigation, K.P. and K.W.; resources, A.A.P., M.I.-H. and A.W.; data curation, P.B. and G.N.; writing-original draft preparation, K.P.; writing-review and editing, A.A.P.; visualization, G.N., K.W., A.W.; supervision, K.W. and M.P.; project administration, A.A.P. and P.B.; funding acquisition, A.A.P. and K.P. All authors have read and agreed to the published version of the manuscript.

Funding: This research received no external funding.

Institutional Review Board Statement: Not applicable.

Informed Consent Statement: Not applicable.

Conflicts of Interest: The authors declare no conflict of interest.

\section{References}

1. Kupczyk, A.; Mączyńska-Sęczek, J.; Golisz, E.; Borowski, P.F. Renewable energy sources in transport on the example of methyl esters and bioethanol. Processes 2020, 8, 1610. [CrossRef]

2. Masjuki, H.M.; Kalam, M.A. An Overview of Biofuel as a renewable energy source: Development and challenges. Procedia Eng. 2013, 56, 53.

3. Pietrzak, K.; Pietrzak, O. Environmental effects of electromobility in a sustainable urban public transport. Sustainability 2020, 12, 1052. [CrossRef]

4. Susmozas, A.; Martín-Sampedro, R.; Ibarra, D.; Eugenio, M.E.; Iglesias, R.; Manzanares, P.; Moreno, A.D. Process strategies for the transition of $1 \mathrm{G}$ to advanced bioethanol production. Processes 2020, 8, 1310. [CrossRef]

5. United Nations Industrial Development Organization. The European Green Deal: Europe's New Growth Strategy A Climate-Neutral EU by 2050; UNIDO Liaison Office in Brussels: Bruxelles, Belgium, 2020.

6. Consiglio, D. Biofuels, fossil energy ratio, and the future of energy production. Phys. Sci. Rev. 2017, 2, 20170055.

7. Demirbas, A. Combustion efficiency impacts of biofuels. In Energy Sources, Part A: Recovery, Utilization, and Environmental Effects; Taylor \& Francis Group: Abingdon-on-Thames, UK, 2009; Volume 31, pp. 602-609.

8. Yoro, K.O.; Daramola, M.O. $\mathrm{CO}_{2}$ emission sources, greenhouse gases, and the global warming effect. In Advances in Carbon Capture; Woodhead Publishing: Sawston, UK, 2020; pp. 3-28.

9. Gąsiorowska, B.; Makarewicz, A.; Płaza, A.; Nowosielska, A. Plon ziarna i cechy kolb kukurydzy wysiewanej w różnych terminach. Fragm. Agron. 2009, 29, 55-63.

10. Zaborowicz, M.; Boniecki, P.; Koszela, K.; Przybyl, J.; Mazur, R.; Kujawa, S.; Pilarski, K. Use of Artificial Neural Networks in the Identification and Classification of Tomatoes. In Proceedings of the 5th International Conference on Digital Image Processing, Beijing, China, 21-22 April 2013; Volume 8878.

11. Ignacy, N.; Mariusz, S.; Rafał, R. Production technology of sugar maize. In Acta Agrophys; Institute of Agrophysics PAS: Lublin, Poland, 2005.

12. da Silva, A.L.; Castaneda-Ayarza, J.A. Macro-environment analysis of the corn ethanol fuel development in Brazil. Renew. Sust. Energy Rev. 2021, 135, 110387. [CrossRef]

13. Stefan, S.; Youngmi, K.; Eduardo, X.; Nathan, M.; Michael, L. Ethanol Production from Maize. In Molecular Genetic Approaches to Maize Improvement; Kriz, A.L., Larkins, B.A., Eds.; Biotechnology in Agriculture and Forestry; Springer: Berlin/Heidelberg, Germany, 2009; Volume 63, pp. 347-364.

14. Eckert, C.T.; Frigo, E.P.; Albrecht, L.P.; Albrecht, A.J.P.; Christa, D.; Santos, W.G.; Berkembrock, E.; Egewarth, V.A. Maize ethanol production in Brazil: Characteristics and perspectives. Renew. Sust. Energy Rev. 2018, 82, 3907-3912. [CrossRef]

15. Achinas, S.; Euverink, G.J.W. Consolidated briefing of biochemical ethanol production from lignocellulosic biomass. Electron. J. Biotechnol. 2016, 23, 44-53. [CrossRef] 
16. Öner, E.T.; Oliver, S.G.; Kirdar, B. Production of ethanol from starch by respiration-deficient recombinant Saccharomyces cerevisiae. Appl. Environ. Microbiol. 2005, 71, 6443-6445. [CrossRef] [PubMed]

17. Stazi, V.; Tomei, M.C. Enhancing anaerobic treatment of domestic wastewater: State of the art, innovative technologies and future perspectives. Sci. Total Environ. 2018, 635, 78-91. [CrossRef]

18. Silva dos Santos, I.F.; Braz Vieira, N.D.; Bruni de Nóbrega, L.G.; Barros, R.M.; Tiago Filho, G.L. Assessment of potential biogas production from multiple organic wastes in Brazil: Impact on energy generation, use, and emissions abatement. Resour. Conserv. Recycl. 2018, 131, 54-63. [CrossRef]

19. Pilarska, A.A.; Pilarski, K.; Ryniecki, A.; Tomaszyk, K.; Dach, J.; Wolna-Maruwka, A. Utilization of vegetable dumplings waste from industrial production by anaerobic digestion. Int. Agrophys. 2017, 31, 93-102. [CrossRef]

20. Pilarska, A.A.; Pilarski, K.; Wolna-Maruwka, A.; Boniecki, P.; Zaborowicz, M. Use of confectionery waste inbiogas production by the anaerobic digestion process. Molecules 2019, 24, 37. [CrossRef]

21. Pilarska, A.A.; Pilarski, K.; Waliszewska, B.; Zborowska, M.; Witaszek, K.; Waliszewska, H.; Kolasiński, M.; Szwarc-Rzepka, K. Evaluation of bio-methane yields for high-energy organic waste and sewage sludge: Apilot-scale study for a wastewater treatment plant. Environ. Eng. Manag. J. 2019, 18, 2023-2034. [CrossRef]

22. Pilarska, A.A.; Wolna-Maruwka, A.; Pilarski, K.; Janczak, D.; Przybył, K.; Gawrysiak-Witulska, M. The use oflignin as a microbial carrier in the co-digestion of cheese and wafer waste. Polymers 2019, 11, 2073. [CrossRef]

23. Chynowetha, D.P.; Owensa, J.M.; Legrand, R. Renewable methane from anaerobic digestion of biomass. Renew. Energy 2001, 22, 1-8. [CrossRef]

24. Pilarska, A.A.; Pilarski, K.; Witaszek, K.; Waliszewska, H.; Zborowska, M.; Waliszewska, B.; Kolasiński, M.; Szwarc-Rzepka, K. Treatment of dairy waste by anaerobic digestion with sewage sludge. Ecol. Chem. Eng. S 2016, 23, 99-115. [CrossRef]

25. Weiland, P. Biogas Production: Current state and perspectives. Appl. Microbiol. Biotechnol. 2010, 85, 849-860. [CrossRef]

26. Pilarski, K.; Pilarska, A.A.; Witaszek, K.; Dworecki, Z.; Zelaziński, T.; Ekielski, A.; Makowska, A.; Michniewicz, J. The impact of extrusion on the biogas and biomethane yield of plant substrates. J. Ecol. Eng. 2016, 17, 264-272. [CrossRef]

27. Witaszek, K.; Pilarska, A.A.; Pilarski, K. Selected methods of vegetable raw material pre-treatment used in biogas production. Ekon. Environ. 2015, 53, 138-152.

28. Ziemiński, K.; Kowalska-Wentel, M. Effect of different sugar beet pulp pretreatments on biogas production efficiency. Appl. Biochem. Biotechnol. 2017, 181, 1211-1227. [CrossRef]

29. Mioduszewska, N.; Pilarska, A.A.; Pilarski, K.; Adamski, M. The influence of the process of sugar beet storage on its biochemical methane potential. Energies 2020, 13, 5104. [CrossRef]

30. Szymańska, M.; Sosulski, T.; Szara, E.; Pilarski, K. Conversion and properties of anaerobic digestates frombiogas production. Przem. Chem. 2015, 94, 1419-1423.

31. Pilarska, A.A.; Pilarski, K.; Wolna-Maruwka, A. Cell immobilization on lignin-polyvinylpyrrolidone material used for anaerobic digestion of waste wafers and sewage sludge. Environ. Eng. Sci. 2019, 36, 478-490. [CrossRef]

32. Pilarska, A.A.; Wolna-Maruwka, A.; Niewiadomska, A.; Pilarski, K.; Olesienkiewicz, A. A Comparison of the influence of kraft lignin and the kraft lignin/silica system as cell carriers on the stability and efficiency of the anaerobic digestion process. Energies 2020, 13, 5803. [CrossRef]

33. Witaszek, K.; Pilarski, K.; Niedbała, G.; Pilarska, A.A.; Herkowiak, M. Energy efficiency of comminution and extrusion of maize substrates subjected to methane fermentation. Energies 2020, 13, 1887. [CrossRef]

34. Lanzerstorfer, C.; Jäger, A. Decentralized integrated biogas and bioethanol production. Sugar Ind. J. 2008, 133, 642-645.

35. Cesaro, A.; Belgiorno, V. Combined biogas and bioethanol production: Opportunities and challenges for industrial application. Energies 2015, 8, 8121-8144. [CrossRef]

36. Martin, M.; Svensson, N.; Fonseca, J.; Eklund, M. Quantifying the environmental performance of integrated bioethanol and biogas production. Renew. Energy 2014, 61, 109-116. [CrossRef]

37. Kotarska, K.; Dziemianowicz, W.; Swierczyńska, A. Study on the sequential combination of bioethanol and biogas production from corn straw. Molecules 2019, 24, 4558. [CrossRef]

38. Marrubini, G.; Papetti, A.; Genorini, E.; Ulrici, A. Determination of the Sugar Content in Commercial Plant Milks by Near Infrared Spectroscopy and Luff-Schoorl Total Glucose Titration. Food Anal. Methods 2017, 10, 1556-1567. [CrossRef]

39. AOAC International. Association of Analytical Chemists Official Method 962.09. Fiber (crude) in animal feed and pet food. In The Official Methods of Analysis of AOAC International, 16th ed.; Cunniff, P., Ed.; AOAC: Rockville, MD, USA, 1995.

40. AOAC International. Association of Analytical Chemists Official Method 920.85. Fat (Crude) or Ether Extract of Flour. In The Official Methods of Analysis of AOAC International, 16th ed.; Cunniff, P., Ed.; AOAC: Rockville, MD, USA, 1995.

41. AOAC International. Association of Analytical Chemists Official Method 920.87. Protein (Total) in Flour. In The Official Methods of Analysis of AOAC International, 16th ed.; Cunniff, P., Ed.; AOAC: Rockville, MD, USA, 1995.

42. AOAC International. Association of Analytical Chemists Official Method 923.03. Ash of Flour. Direct Method. In The Official Methods of Analysis of AOAC International, 16th ed.; Cunniff, P., Ed.; AOAC: Rockville, MD, USA, 1995.

43. Pilarska, A.A. Anaerobic co-digestion of waste wafers from the confectionery production with sewage sludge. Polish J. Environ. Stud. 2018, 27, 237-245. [CrossRef] 
44. Pilarska, A.A.; Wolna-Maruwka, A.; Niewiadomska, A.; Pilarski, K.; Adamski, M.; Grzyb, A.; Grządziel, J.; Gałązka, A. Silica/lignin carrier as a factor increasing the process performance and genetic diversity of microbial communities in laboratoryscale anaerobic digesters. Energies 2021, 14, 4429. [CrossRef]

45. DIN Guideline 38 414-S8. Characterisation of the Substrate, Sampling, Collection of Material Data, Fermentation Tests; German Institute for Standardization: Berlin, Germany, 1985.

46. ISO. Guide to the Expression of Uncertainty in Measurement (GUM); ISO: Geneva, Switzerland, 1993.

47. Konieczka, P.; Namieśnik, J. Evaluation and Quality Control of Analytical Measurement Results; Scientific-Technical Publishing House WNT: Warsaw, Poland, 2007.

48. Pilarski, K.; Pilarska, A.A.; Boniecki, P.; Niedbała, G.; Durczak, K.; Witaszek, K.; Mioduszewska, N.; Kowalik, I. The efficiency of industrial and laboratory anaerobic digesters of organic substrates: The use of the Biochemical Methane Potential Correction Coefficient. Energies 2020, 13, 1280. [CrossRef]

49. Kumar, D.; Singh, V. Bioethanol Production From Corn. Chem. Technol. 2019, 22, 615-631.

50. Luque, L.; Oudenhoven, S.; Westerhof, R.; van Rossum, G.; Berruti, F.; Kersten, S.; Rehmann, L. Comparison of ethanol production from corn cobs and switchgrass following a pyrolysis-based biorefinery approach. Biotechnol. Biofuels 2016, 9, 242. [CrossRef] [PubMed]

51. Chen, M.-H.; Kaur, P.; Dien, B.; Below, F.; Vincent, M.L.; Singh, V. Use of tropical maize for bioethanol production. World J. Microbiol. Biotechnol. 2013, 29, 1509-1515. [CrossRef]

52. Torney, F.; Moeller, L.; Scarpa, A.; Wang, K. Genetic engineering approaches to improve bioethanol production from maize. Curr. Opin. Biotechnol. 2007, 18, 193-199. [CrossRef]

53. Milanez, A.Y.; Nyko, D.; Valente, M.S.; Xavier, C.E.O.; Kulay, L.A.; Donke, C.G.; Matsuura, M.I.S.F.; Ramos, N.P.; Morandi, M.A.B.; Bonomi, A.; et al. A produção de etanol pela integração do milho-safrinha às usinas de cana-de-açúcar: Avaliação ambiental, econômica e sugestões de política. Revista BNDES 2014, 41, 147-208.

54. Quintero, J.A.; Montoya, M.A.; Sánchez, O.J.; Giraldo, O.H.; Cardona, C.A. Fuel ethanol production from sugarcane and corn: Comparative analysis for a Colombian case. Energy 2008, 33, 385-399. [CrossRef]

55. Boniecki, P.; Nowakowski, K.; Tomczak, R.Ł. Neural networks type MLP in the process of identification chosen varieties of maize In Proceedings of the 3rd International Conference on Digital Image Processing, Chengdu, China, 15 April 2011 ; Volume 8009.

56. Nowakowski, K.; Boniecki, P.; Dach, J. The Identification of mechanical damages of kernels basis on neural image analysis. In Proceedings of the International Conference on Digital Image Processing, Bangkok, Thailand, 7-9 March 2009 ; pp. $412-415$.

57. Sariningpuri, J.M.; Rifin, A.; Hasbullah, R. The competitiveness of manual and mechanized corn cultivation. Indones J. Bus. Entrep. 2017, 3, 24-33. [CrossRef]

58. Miles, M.J.; Morris, V.J.; Orford, P.D.; Ring, S.G. The roles of amylose and amylopectin in the gelation and retrogradation of starch. Carbohydr. Res. 1985, 135, 271-281. [CrossRef]

59. Cai, C.; Zhao, L.; Huang, J.; Chen, Y.; Wei, C. Morphology, structure and gelatinization properties of heterogeneous starch granules from high-amylose maize. Carbohydr. Polym. 2014, 102, 606-614. [CrossRef] [PubMed]

60. Rubio-Arroyo, M.F.; Vivanco-Loyo, P.; Juárez, M.; Poisot, M.; Ramírez-Galicia, G. Bio-ethanol obtained by fermentation process with continuous feeding of yeast. J. Mex. Chem. Soc. 2011, 55, 242-245.

61. Palanisamy, C.P.; Cui, B.; Zhang, H.; Muthukaliannan, S.J.G.K. A comprehensive review on corn starch-based nanomaterials: Properties, simulations, and applications. Polymers 2020, 12, 2161. [CrossRef] [PubMed]

62. Roder, N.; Ellis, P.R.; Butterworth, P.J. Starch molecular and nutritional properties: A review. Adv. Mol. Med. 2005, 1, 5-14.

63. Pilarska, A.A.; Wolna-Maruwka, A.; Pilarski, K. Kraft lignin grafted with polyvinylpyrrolidone as a novel microbial carrier in biogas production. Energies 2018, 11, 3246. [CrossRef]

64. Nair, R.B.; Kabir, M.M.; Lennartsson, P.R.; Taherzadeh, M.J.; Horváth, I.S. Integrated process for ethanol, biogas, and edible filamentous fungi-based animal feed production from dilute phosphoric acid-pretreated wheat straw. Appl. Biochem. Biotechnol. 2018, 184, 48-62. [CrossRef]

65. Martin, M.; Svensson, N.; Fonseca, J. Assessing the Environmental Performance of Integrated Ethanol and Biogas Production. In Proceedings of the World Renewable Energy Congress 2011—Sweden, Linköping, Sweden, 8-11 May 2011.

66. Oleskowicz-Popiel, P.; Lisiecki, P.; Holm-Nielsen, J.B.; Thomsen, A.B.; Thomsen, M.H. Ethanol production from maize silage as lignocellulosic biomass in anaerobically digested and wet-oxidized manure. Bioresour. Technol. 2008, 99, 5327-5334. [CrossRef]

67. Papa, G.; Rodriguez, S.; George, A.; Schievano, A.; Orzi, V.; Sale, K.L.; Singh, S.; Adani, F.; Simmons, B.A. Comparison of different pretreatments for the production of bioethanol and biomethane from corn stover and switchgrass. Bioresour. Technol. 2015, 183, 101-110. [CrossRef]

68. Moshi, A.P.; Crespo, C.F.; Badshah, M.; Hosea, K.M.M.; Mshandete, A.M.; Elisante, E.; Mattiasson, B. Characterisation and evaluation of a novel feedstock, Manihot glaziovii, Muell. Arg, for production of bioenergy carriers: Bioethanol and biogas. Bioresour. Technol. 2014, 172, 58-67. [CrossRef] [PubMed]

69. Leitner, V.; Lindorfer, J. Evaluation of technology structure based on energy yield from wheat straw for combined bioethanol and biomethane facility. Renew. Energy 2016, 87, 193-202. [CrossRef]

70. Barta, Z.; Reczey, K.; Zacchi, G. Techno-economic evaluation of stillage treatment with anaerobic digestion in a softwood-toethanol proces. Biotechnol. Biofuels 2010, 3, 21. [CrossRef] [PubMed] 